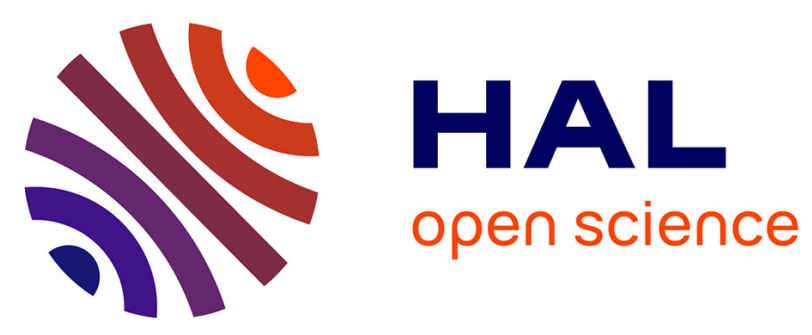

\title{
INTEGRATION OF BIODEGRADATION AND MIGRATION OF HYDROCARBONS IN A 2D PETROLEUM SYSTEMS MODEL: APPLICATION TO THE POTIGUAR BASIN, (BRAZIL)
}

Mathieu Ducros, Bernard Carpentier, Sylvie Wolf, Marie-Christine Cacas

\section{To cite this version:}

Mathieu Ducros, Bernard Carpentier, Sylvie Wolf, Marie-Christine Cacas. INTEGRATION OF BIODEGRADATION AND MIGRATION OF HYDROCARBONS IN A 2D PETROLEUM SYSTEMS MODEL: APPLICATION TO THE POTIGUAR BASIN, (BRAZIL). Journal of Petroleum Geology, 2016, 39 (1), pp.61-78. 10.1111/jpg.12628 . hal-01258755

\section{HAL Id: hal-01258755 https://hal.science/hal-01258755}

Submitted on 19 Jan 2016

HAL is a multi-disciplinary open access archive for the deposit and dissemination of scientific research documents, whether they are published or not. The documents may come from teaching and research institutions in France or abroad, or from public or private research centers.
L'archive ouverte pluridisciplinaire HAL, est destinée au dépôt et à la diffusion de documents scientifiques de niveau recherche, publiés ou non, émanant des établissements d'enseignement et de recherche français ou étrangers, des laboratoires publics ou privés. 


\section{Integration of biodegradation and migration of hydrocarbons in a}

\section{2 petroleum system model: Application to the Potiguar Basin (Brazil)}

4 Mathieu Ducros*, Bernard Carpentier, Sylvie Wolf, Marie-Christine Cacas.

5

6 IFP Énergies nouvelles, Direction Géologie-Géochimie-Géophysique, 1 et 4 avenue de 7 Bois-Préau, 92852 Rueil-Malmaison Cedex - France.

$9 *$ Corresponding author.

10 E-mail address: mathieu.ducros@ifpen.fr (M. Ducros)

\section{ABSTRACT}

13 Prediction of oil quality is a major issue as exploration extends towards costlier areas

14 such as high water depth basins. Biodegradation, responsible for the major part of heavy

15 oil reservoirs in the world (Roadifer, 1987), is the most important oil alteration process.

16 Several studies have already been performed to determine qualitative biodegradation

17 scales (Moldowan et al., 1992; Peters et al., 2005) or quantitative levels of

18 biodegradation through basin and petroleum system modeling (Larter et al., 2003;

19 Walters et al., 2009).

20 Until now, the different proposed approaches to simulate biodegradation processes and

21 quantify their impact on the quality of trapped hydrocarbons remain post-processing

22 solutions. This is not fully satisfactory due to the complexity of the history of a

23 petroleum system and of the processes involved (generation, migration, alteration,

24 preservation...). For instance, mixing of biodegraded and fresh oil, as well as effects of 
25 viscosity changes on migration, are poorly taken into account. Moreover, the

26 description and the evolution through time of the oil-water contact, which is known to

27 play a key role in the biodegradation (e.g. Larter et al., 2003), are usually over-

28 simplified.

29 In our work we integrated the biodegradation processes within a basin and petroleum

30 system forward simulator. Based on a Darcy's migration calculator, we simulated the

31 evolution through time of hydrocarbon properties. An innovative way to determine the

32 intensity of microbial activity and the evolution of the oil-water contact, where

33 biodegradation is confined, has been developed. This new approach has been applied on

34 the Potiguar basin and it appeared that besides the residence time in the biodegradation

35 temperature window, rate of reservoir infill and migration paths are key controlling

36 factors of the biodegradation. Our results fit satisfactorily the observed data and

37 highlight the improvements brought by a fully coupled approach to the determination of

38 oil quantity, quality and migration timing. 
41 Biodegradation is a complex series of bio-chemical processes of decomposition of

42 organic matter by micro-organisms in the subsurface. These processes, which generally

43 involve a pool of micro-organisms working in association (e.g. Dolfing et al., 2008),

44 result mainly in the generation of methane and carbon dioxide from hydrocarbons (e.g.

45 Zengler et al., 1999). If biodegradation risk is not accounted for, it can lead to lower

46 revenues than expected due to high hydrocarbon density and viscosity, increase of

47 corrosion risks, increase of refining costs, etc...

48 Among others, organic matter richness and maturity, hydrocarbon expulsion, migration

49 and preservation are of uppermost importance when assessing oil quantity and quality.

50 Biodegraded oils are considered to represent the main part (bituminous and heavy oils)

51 of the world petroleum reserves (Roadifer, 1987) and should be very common in future

52 deep water discoveries like in the Atlantic African margin (Head et al., 2003). In that

53 context of very high drilling costs, prediction of oil quality becomes a critical issue

54 since it is a major control of cost-effectiveness.

55 Recent advances in the understanding of the biodegradation processes open the way to

56 the quantitative modeling of their effects. Several researches have already been

57 performed to provide tools for characterizing oil biodegradation by determining

58 qualitative biodegradation scales (Connan, 1984; Johns, 1986; Moldowan et al., 1992;

59 Yu et al., 2002; Peters et al., 2005) or quantitative levels of biodegradation in reservoirs

60 (Larter et al., 2003; Blumenstein et al., 2008; Dzou et al., 2009; Walters et al., 2009;

61 Haeseler et al., 2010). Most of these models consider biodegradation processes

62 occurring in the reservoir apart from the basin history and without information on

63 hydrocarbon migration. 
64 As noticed by Blumenstein et al. (2008), it is natural to tie biodegradation processes,

65 migration processes and petroleum system evolution. Most of the latter works tended to

66 make the link between hydrocarbon migration and biodegradation. Before the first

67 attempts to link biodegradation processes and petroleum system modeling, some authors

68 had already worked at the geological scale to provide qualitative tools for the

69 description and the prediction of the biodegradation risk in reservoirs. Wenger et al.

70 (2001) and Peters et al. (2005) proposed for instance a biodegradation qualitative scale

71 based mostly on empirical field observations where biodegradation processes are

72 considered as stepwise processes. Then Yu et al. (2002) proposed a numerical solution,

73 providing results as a qualitative risk, called BDI (Biodegradation Index). This

74 numerical model was designed to qualitatively predict the biodegradation degree of

75 hydrocarbons as a function of temperature history and of residence time of oil in the

76 reservoir. It had to be used carefully as it did not take into account the dynamic of

77 petroleum charge. Moreover BDI formulation assumed a simple thermal history (no

78 uplift and no erosion) because potential paleopasteurization were not taken into account

79 in the case of complex geological history. Wilhelms et al. (2004) improved this

80 approach by adding a term which accounted for reservoir filling history. It was still not

81 fully coupled to the petroleum system modeling and did not take into account some

82 important phenomena such as oil mixing and reservoir spilling.

83 A much more documented and quantitative approach was developed by Larter et al.

$84(2003,2006)$. Their solution added the notion of degradation flux (expressed in $\mathrm{kg} \mathrm{m}^{-2}$

$85 \mathrm{y}^{-1}$ ) derived from laboratory experiments (Larter et al., 2006). Their work resulted in a

86 first method to quantitatively assess biodegradation risk. Blumenstein et al. (2008), who

87 pointed out the limitations of the previous solutions described here above, aimed at 
88 improving the modeling of biodegradation processes in their Biodexx approach by

89 strengthening the link with petroleum system history. Thus, they focused their work on

90 the effects of reservoir geometry, filling rates and oil composition in the reservoir.

91 However, all these solutions are still based on post-processing calculations what cannot

92 be fully satisfactory to properly quantify biodegradation effects. Indeed it is absolutely

93 essential to fully combine migration and biodegradation mechanisms in order to

94 properly take into account the effects (i) of mixing of biodegraded and fresh oil (which

95 changes petroleum properties), (ii) of biodegradation processes during reservoir filling

96 (which can delay spilling and thus reduce distance of petroleum migration) and (iii) of

97 the control of biodegradation on oil viscosity and density regarding to migration.

98 Besides a poor link between biodegradation model and petroleum system simulation in

99 the previous approaches, the description of biodegradation location was either vague or

100 arbitrary and did not take reservoir porosity and permeability into account. As a

101 consequence, there was no difference that could be accounted for in the description of

102 the biodegradation between reservoirs of unequal quality (in terms of permeability and

103 porosity) reducing at the same time the prediction capability of the models. It appears

104 also important to mention that theses approaches are generally based on schematic

105 representations of reservoir architecture (Larter et al., 2003) and its evolution through

106 time was barely taken into account, as well as input parameters such as temperature

107 which has to be adjusted manually (Blumenstein et al., 2008).

108 The present work aims at developing a new approach for determining hydrocarbon

109 losses and oil quality evolutions, using a methodology based on biodegradation rates

110 and on previous case studies (Carpentier et al., 2005; Behar et al., 2006; de Barros

111 Penteado et al., 2007). It is integrated in a petroleum system modeling (PSM) simulator, 
112 thus allowing for biodegradation processes model to be fully coupled with migration

113 simulation. The proposed approach was tested on a $2 \mathrm{D}$ numerical model of the Potiguar

114 Basin (Brazil) which is well known thanks to several studies conducted in the past

115 (Trindade et al., 1992; Blanchet et al., 2005; de Barros Penteado et al., 2007).

117 2. Methodology: description of the conceptual model

118 PSM aims at assessing and de-risking prospect evaluation in petroleum exploration. It

119 uses information on the reconstruction of the basin history to describe, in a deterministic

120 manner, the main mechanisms impacting reservoirs potential. Therefore, as a basic,

121 PSM calculates burial history, thermal history and pressure fields which control source

122 rock maturity, expulsion, migration and hydrocarbon trapping. It seems natural to

123 introduce biodegradation concepts within PSM since on one hand it can greatly impact

124 the reservoirs potential and the prospect evaluation and on the other hand PSM provides

125 most of the parameters controlling biodegradation (oil composition and oil quantity,

126 temperature,...) to rigorously describe biodegradation processes.

127 Even if biodegradation processes are better understood thanks to recent works (e.g.

128 Zengler et al., 1999; Head et al., 2003; Jones et al., 2008; Dolfing et al., 2008), the

129 controlling parameters, at basin scale, of the mechanisms involved are still not clearly

130 known. Although some authors consider that nutrients supply can be a limiting factor of

131 biodegradation processes (Head et al., 2003) there is still no clear evidence of such

132 effects at the basin scale. In that context we adopted an approach based on several

133 concepts commonly accepted corresponding to the description of macro scale

134 consequences (loss of hydrocarbon) of micro scale biodegradation processes

135 (decomposition of hydrocarbons into methane and carbon dioxide by a pool of micro- 
136 organisms working in association). Biodegradation being a microbial process, it only

137 works within the range of temperatures within which micro-organisms can live. When

138 temperature exceeds the micro-organisms living temperature (pasteurization

139 temperature) the rock is pasteurized and no more biodegradation can occur. Therefore,

140 at a given time, biodegradation processes are restricted to the zones where the

141 pasteurization temperature has never been reached and where oil saturation is in a

142 limited range. This saturation range where oil alteration can take place corresponds to

143 the transition zone between water saturated and oil saturated zone, often referred to as

144 the reservoir oil-water contact, but it can also correspond to low hydrocarbon velocity

145 migration paths. As biodegradation is restricted to a zone where hydrocarbon is

146 abundant, it has been assumed that microbial population is not limited by the

147 hydrocarbon quantity but by a parameter (such as nutrient concentration) which is

148 related to the deposited rock property. There is therefore a reference microbial

149 population corresponding to the deposition conditions that evolves during burial as a

150 function of the available space. Microbial consumption is assumed to be a zero order

151 mechanism which relies only on the microbial population and to the microbial activity,

152 closely linked to the temperature. Biodegradation being a compositional process,

153 differential consumption rates are assigned to chemical compounds as a function of their

154 biodegradability. As the products of the biodegradation reactions (mostly methane and

155 carbon dioxide) are not found in much higher quantities in biodegraded fields than in

156 nearby non degraded fields (Head et al., 2003), they are not taken into account in the

157 approach followed in this work. Thus, biodegradation is considered as being only

158 destructive. 
159 From the petroleum system point of view, the close integration of biodegradation

160 mechanisms in basin models directly improves the modeling of the petroleum properties

161 such as density or viscosity giving more accurate results in terms of reservoirs filling,

162 spilling and migration timing what would not be achieved with a post-processing 163 approach.

\subsection{Biodegradation location}

166 Previous works have demonstrated that biodegradation processes occur mostly at the

167 oil-water contact (e.g. Head et al., 2003; Larter et al., 2003). However some authors

168 have also admitted that it could not be restricted only to reservoirs oil-water contact but

169 that it could also occur in migration paths (Larter et al., 2003). In order to account for

170 the locations where biodegradation can take place, the solution mainly adopted (Larter

171 et al., 2003; Blumenstein et al., 2008) consists in determining the surface area of the oil-

172 water contact within the reservoir and using a biodegradation rate per unit area of this

173 oil-water contact (e.g. Larter et al., 2003; Blumenstein et al., 2008). This approach

174 oversimplifies the problem because the oil-water contact is in fact a transition zone

175 whose thickness depends on the capillary pressure and on the oil density. So, using the

176 surface of the base of the oil accumulation in the reservoir as a controlling parameter of

177 biodegradation does not account accurately for the global biodegradation rate. Secondly

178 biodegradation process are restricted to reservoir oil-water contact described on the base

179 of arbitrary criteria, though they can also occur the migration paths.

180 In the model developed during this work, to account for micro-organisms requiring both

181 water and hydrocarbon to develop, we assumed that microbial population is optimal

182 (and limited by the available space as we will described it in the following section) only 
183 in a restricted range of oil saturations. This latter range leads to the restriction of

184 biodegradation process to the oil-water transition zone in reservoirs and potentially to 185 some parts of the migration path where hydrocarbon movements are slowed down. We 186 adopted this new approach to precisely control locations and involved volumes where 187 biodegradation processes can take place. This is done based on a range of oil saturation 188 and without any hypothesis on the definition of a potential trap or on the way the 189 reservoir is filled.

190 Generally mesh thicknesses used in basin modeling are too coarse to represent properly 191 the oil-water transition zone, especially in good reservoirs. Grid cells are usually tens of

192 meters thick while oil-water contacts are several meters thick. In order to be able to

193 determine the volume of the oil-water transition zone independently of the mesh

194 geometry we used the capillary pressure and the oil density to compute its thickness.

195 This transition zone, also referred to in the following as the oil-water contact zone, is 196 used to determine the zone where biodegradation can take place (Fig. 1). In a general

197 formulation, the thickness of the transition zone (the thickness in which the saturation is 198 assumed to vary linearly from the maximum oil saturation in the rock to the irreducible 199 oil saturation at the base of the oil-water contact) is given by the following expression:

$$
\text { Thick }_{O W C}=\frac{\Delta P c}{\Delta \rho g}
$$

201 Where Thick ${ }_{O W C}$ is the thickness of the oil-water contact (transition zone), $\triangle P c$ is the

202 variation of capillary pressure between the top and the base of the transition zone, $g$ is

203 the gravity and $\Delta \rho$ is the difference of density between the water and the petroleum

204 phase. As it has been assumed that biodegradation takes place in a restricted range of 
saturations, thickness of the biodegradation interval is smaller than that of the transition

206 zone.

207 One of the great advantages of this method relies on the fact that no assumption other

208 that the presence of reactants is needed for determining the location of the

209 biodegradation processes.

2112.2 Micro-organisms density and oil consumption

212 Some authors have investigated the microbial population density in sediments (e.g.

213 Cragg et al., 1999). Thanks to the extensive amount of data provided by the Ocean

214 Drilling Program (ODP), a lot of microbial population measurements have been

215 performed and analyzed. Cragg et al. (1999) for instance derived a microbial population

216 law from ODP data (e.g. Cragg et al, 1997; Parkes et al., 2000) given by the following

217 expression:

218

$$
\log _{10}(\text { bacterial number })=7.95-0.64 \log _{10}(\text { depth in } \mathrm{m})
$$

219 As measurements were not performed in hydrocarbon reservoirs, corresponding

220 microbial pools are surely not exactly the same as the one responsible for hydrocarbon

221 biodegradation. However the evolution of the microbial pool, at geological time-scale,

222 can be considered as responding instantaneously to changes on environmental

223 conditions. Therefore, it is assumed that information on the evolution of microbial

224 population through burial obtained in ODP programs could be extrapolated to microbial

225 population responsible for hydrocarbon biodegradation.

226 The model proposed by Cragg et al. (1997) which reproduces the measurements

227 performed during the ODP is based on a relationship between the microbial population 
and the depth. Thus it relies more on empirical observations than on a real deterministic

229 concept. In order to express the evolution of the microbial population in sediments we

230 assumed that, at the pore scale, micro-organisms are located at the oil-water interface.

231 We use a simple model of the rock micro-structure in which pores are represented by

232 spheres and where the number of pores per unit of solid volume depends on the

233 lithology and remains constant during burial. Thus porosity reduction during the burial

234 is accounted for through pore volume reduction and not through pore number decrease.

235 The oil present in the pores is also represented as a bubble totally surrounded by water

236 (Fig. 2). With these hypothesis we can express the evolution of the microbial population

237 as a function of the lithology and of the porosity.

238 The number of pores in the rock ( $\mathrm{m}^{-3}$ of bulk rock) is given by the following expression:

$$
n_{\text {pores }}=d(1-\varphi)
$$

240 where $d$ is the pore density for the given rock $\left(\mathrm{m}^{-3}\right.$ of solid rock) and $\varphi$ is the rock

241 porosity.

242 Using this micro-structure rock model, the rock porosity can be expressed as follows:

$$
\varphi=d(1-\varphi) \frac{4}{3} \pi R^{3}
$$

244 where $R$ is the pore radius as illustrated in Fig. 2. Thus the corresponding pore radius 245 can be deduced:

$$
R=\sqrt[3]{\frac{3 \varphi}{4 d \pi(1-\varphi)}}
$$

247 The hypothesis on oil distribution within porosity leads to the following expression of

248 the contact area between oil and water in the porosity $\left(\mathrm{m}^{2} / \mathrm{m}^{3}\right.$ of bulk rock): 
250 where $r$ is the oil drop radius as illustrated in Fig. 2 and $a$ the oil-water surface area by 251 unit of rock volume.

252 The oil saturation can be expressed as follows:

$$
S=\frac{r^{3}}{R^{3}}
$$

254 where $S$ is the oil saturation. Combining the previous equations, the oil-water interface

255 area in the porosity can be expressed as a function of the oil saturation:

$$
a=4 d \pi(1-\varphi) R^{2} S^{2 / 3}
$$

257 Then, using the hypothesis of vertical linear saturation profile (which is a handy and reasonable approximation of the true saturation profile), $S$, along the oil-water contact

259 ( $h=0$ at the base of the oil-water contact and $h=T h i c k_{\text {OWC }}$ at the top of the oil-water 260 contact):

$$
S(h)=\frac{h}{\text { Thick }_{\text {OWC }}}
$$

262 and assuming that the porosity does not change significantly within the oil-water

263 contact zone (which can be considered as being homogeneous and too thin to

264 experience significant porosity variations), the mean oil-water interface area in the transition zone can be approximated as follows:

$$
\bar{a}=\frac{1}{\text { Thick }_{\text {OWC }}} \int_{0}^{\text {Thick }_{\text {OWC }}} a(h) d h
$$

thus 


$$
\bar{a}=\frac{1}{\text { Thick }_{\text {OWC }}} \int_{0}^{\text {Thick }_{\text {OWI }}} 4 d \pi(1-\varphi) R^{2}\left(\frac{h}{\text { Thick }_{\text {OWC }}}\right)^{2 / 3} d h
$$

269 Then, using equation (5), the cumulated area of contact surface between oil and water in

270 the transition zone is given by the following formula:

$$
\bar{a}=2.9 \sqrt[3]{d}(1-\varphi)^{1 / 3} \varphi^{2 / 3}
$$

272 Finally an expression can be proposed to compute the microbial population by unit of rock volume in the oil-water contact zone:

$$
N(\varphi)=N_{0}\left(\frac{1-\varphi}{1-\varphi_{0}}\right)^{1 / 3}\left(\frac{\varphi}{\varphi_{0}}\right)^{2 / 3}
$$

275 Where $N_{0}$ corresponds to a reference microbial population at a reference porosity $\varphi_{0}$.

276 Assuming a classical porosity versus depth function $\varphi=\varphi_{\text {surface }} e^{-k z}$ a comparison can

277 me made between the resulting microbial population determined through this new

278 approach with the one proposed by Cragg et al. (1999). Imposing the same microbial 279 population at a depth of $1000 \mathrm{~m}$ (equation 14) leads, for typical values of $k=7 \times 10^{-4}$ 280 and $\varphi_{\text {surface }}=0.5$, to $C=1491640$.

$$
C\left(1-\varphi_{\text {surface }} e^{-1000 \cdot k}\right)^{1 / 3} e^{2 / 3000 \cdot k}=10^{\left(7.95-0.64 \log _{10}(1000)\right)}
$$

282 The comparison of the evolution of microbial population with the Cragg et al.'s (1999)

283 formula and the one derived from the approach proposed in this work is illustrated in

284 Fig. 3. It demonstrates a close behavior of the two models between 800 and $2500 \mathrm{~m}$.

285 The differences observed at shallower depths are not important in regard of the dispersal 286 of measurements. The model based on the evolution of porosity proposed in this work 
287 falls in the $95 \%$ confidence interval of the model derived by Cragg et al. (1999). This

288 comparison should be interpreted with caution since the two considered microbial

289 populations can be very different, the first one corresponding to a global population and

290 the second one to the microbial population responsible for methanogenesis in petroleum

291 reservoirs. However, if one considers the hypothesis that microbial pool is constantly

292 adapting to its environmental conditions, the model is in agreement with ODP measures

293 and uses parameters available in basin modeling.

294 The model relating microbial population with porosity proposed in this work assumes

295 that micro-organisms are located at the interface between the water and the drops of oil.

296 However following the same reasoning but assuming that micro-organisms are located

297 at the surface of the rock would lead to proportional results. Indeed, the surface

298 available for micro-organisms would be in that case:

$$
a^{*}=4 d \pi(1-\varphi) R^{2}
$$

300 Thus the mean oil-water interface area in the transition zone can be expressed as 301 follows:

$$
\bar{a}^{*}=\frac{1}{\text { Thick }_{\text {OWC }}} \int_{0}^{\text {Thick }_{\text {OHC }}} 4 d \pi(1-\varphi) R^{2} d h
$$

303 Resulting again in:

$$
\bar{a}^{*}=4.8 \sqrt[3]{d}(1-\varphi)^{1 / 3} \varphi^{2 / 3}
$$

305 Considering that microbial individual capacity to degrade hydrocarbons is mainly

306 dependent on the temperature, the global biodegradation capacity can then be approximated by the following equation: 


$$
M_{h b}=M_{0}\left(\frac{1-\varphi}{1-\varphi_{0}}\right)^{1 / 3}\left(\frac{\varphi}{\varphi_{0}}\right)^{2 / 3}
$$

where $M_{h b}$ is the mass of hydrocarbon degraded by the microbial population in

$310 \mathrm{~kg} / \mathrm{My} / \mathrm{m}^{3}$ of rock and $M_{0}$ is the reference mass in $\mathrm{kg} / \mathrm{My} / \mathrm{m}^{3}$ of hydrocarbons degraded

311 by the microbial population at the reference porosity $\varphi_{0}$ of rock.

312 The choice of the texture (Fig. 2) was made arbitrarily to obtain evolutions of microbial

313 population versus porosity simple to compute using basin model parameters. However even with alternative models of texture the resulting evolutions of microbial population would not lead to drastically different biodegradation results.

\subsection{Microbial activity}

318 In the previous section, the variation of microbial population as a function of the

319 available space in rock has been described. It is also known that some factors can have 320 impacts on the microbial activity. Previous works already emphasized for instance the

321 importance of temperature as a controlling parameter of the biodegradation rate

322 (Wilhelms et al., 2004; Adams et al., 2006; Larter et al., 2006). Some authors also

323 pointed out that salinity (Bernard et al., 1992), water flux (Head et al., 2003; Larter et

324 al., 2003) or nutrients presence (Head et al., 2003) can also significantly control the

325 biodegradation rate. However impacts of these latter parameters are not well constrained 326 and there is still not a consensus on their importance. Thus, it makes sense to assume

327 that these factors have a second order control on microbial activity.

328 In the approach presented here, on a first order approximation, only the role of

329 temperature and of available space on hydrocarbon consumption rate are considered: 


$$
M_{h b}=M_{0}\left(\frac{1-\varphi}{1-\varphi_{0}}\right)^{1 / 3}\left(\frac{\varphi}{\varphi_{0}}\right)^{2 / 3}
$$

331 where $R(T)$ is the coefficient of microbial activity whose value is between 0 and 1 and

332 which depends on temperature (see section below).

333 Besides controlling the microbial activity, temperature can also pasteurize rocks. Even

334 if the threshold temperature is not well constrained (e.g. Wilhelms et al., 2001; Head et 335 al., 2003), it is commonly admitted that a rock that would have experienced temperature 336 above a threshold around $90^{\circ} \mathrm{C}$ should be pasteurized. The algorithm designed during

337 this work takes into account this concept of paleo-pasteurization. If temperature reaches

338 the temperature threshold corresponding to pasteurization, biodegradation rate is

339 permanently set to 0 for the given cell even if the cell temperature drops below the

340 threshold afterwards. The underlying hypothesis is that there is no movement of micro-

341 organisms at basin scale after sedimentation, even by water advection.

\subsection{Consumption preferences and compositional description of petroleum}

344 Biodegradation modelling requires a compositional description of the hydrocarbon

345 phase in order to be able to represent the differential biodegradability of the different

346 hydrocarbon molecules (e.g. Haeseler et al., 2010). It also needs a model of

347 thermogenic transformation of organic matter and of hydrocarbon fluids in order to be

348 able to simulate the complete petroleum system history including migration from source

349 rock to reservoirs. Consequently, the description of the hydrocarbon fluids must account

350 for PVT, for thermogenic transformation of the organic matter and for biogenic aspects. 
351 This detailed petroleum model is also essential to simulate properties changes in the

352 hydrocarbon fluid such as viscosity or density.

353 The numerical approach proposed in this work to account for biodegradation is similar

354 to the post-processing tool proposed by Haeseler et al. (2010) with the additional notion

355 of degradation rate. The global mass of hydrocarbon biodegraded by micro-organisms is

356 calculated at each time step using equation (19). This mass is then distributed between

357 the biodegradable compounds according to the microbial consumption preferences.

358 When one of the biodegradable compounds has completely disappeared, consumption

359 preferences are normalized on the remaining biodegradable compounds so that all the

360 biodegradation capability of the micro-organisms is used. This means that it is assumed

361 that microbial species evolved in parallel with the change in composition in order to

362 adapt to their new environment, conserving their overall consumption capability.

\subsection{Biodegradation index}

365 In a natural system, defining of a biodegradation index which measures the

366 biodegradation advancement of a given hydrocarbon mixture is quite difficult for two

367 reasons at least, as it has to integrate the effects of mixing between fresh and degraded

368 oil and the effects of secondary cracking. However, such a criterion is necessary for

369 comparing estimated losses from in-situ measurements and from numerical models.

370 Although the petroleum system model gives access to the final composition of the

371 hydrocarbon fluids and thus to a complete information about its economical value, a

372 biodegradation index integrating information about the complete evolution of the 
373 hydrocarbon composition to be compared to measurements would strengthen the

374 prediction and help to evaluate the reliability of the model.

375 Nickel and vanadium concentrations have proved to provide good indications of

376 hydrocarbon losses due to biodegradation (Magnier et al., 2001; Kowalewski et al.;

377 2001). Even if some authors are reluctant to use this methodology (Head et al., 2003),

378 it remains one of the most common and accessible method to quantify these losses. A

379 method to compute a concentration index which would give an information directly

380 comparable with the nickel/vanadium variations of concentration between non-degraded

381 and degraded oils was added to the biodegradation calculation developed during this

382 work.

383 Thus, besides the quantitative description of the effects of biodegradation on migration

384 velocity through viscosity changes and on oil quality, a tracer concentration index is

385 calculated. It is used to define a quantitative indicator of the biodegradation magnitude,

386 in addition to the oil composition which is calculated by the simulator.

387 The biodegradation index is designed to account for the same processes as those which

388 control the concentration of biodegradation resistant compounds such as nickel and

389 vanadium into the petroleum phase. Thus, a fictitious tracer was numerically introduced

390 in the hydrocarbon phase generated by the source rock. The increase of its concentration

391 due to secondary cracking effects and biodegradation effects (main phenomenon that

392 leads to loss of hydrocarbons in the petroleum phase) enables to compute the

393 hydrocarbon mass loss. The value of the concentration index is then defined as follows:

$$
C I=1-\frac{[T]_{\text {generatel }}}{[T]_{\text {current }}}
$$


395 where $C I$ is the concentration index, $[T]_{\text {generated }}$ is the tracer concentration in the 396 generated oil and $[T]_{\text {current }}$ is the tracer concentration in the current oil phase.

\section{3. Application: The Potiguar Basin (Brazil)}

\section{$399 \quad 3.1$ Geological setting}

400 The Potiguar Basin is the most northeastern basin of the Brazilan equatorial margin,

401 covering part of the states of Rio Grande do Norte and Ceará. Around 30\% of its

$40270,000 \mathrm{~km}^{2}$ area is located onshore (Behar et al., 2006), whereas the offshore area

403 extends beyond the continental platform to water depths of at least 2000m (Bertani et

404 al., 1990). (Fig. 5)

405 The Potiguar Basin is typical of most brazilian marginal rifted basins that formed during

406 the breakup between South America and Africa during the Neocomian age. It can be

407 considered as a rift basin that evolved to a passive margin. Sedimentary filling of the

408 basin took place from the Early Cretaceous to the present days and the sedimentary

409 sequences can be 8 kilometers thick. The major structural features and sedimentary

410 bodies of the Potiguar Basin are closely related to the processes and tectonic

411 mechanisms occurring during the opening of the Atlantic ocean.

412 Bertani et al. (1990) recognized 3 main tectono-stratigraphic sequences that characterize

413 the evolution of the Potiguar Basin: rift, transitional and drift stages of continent

414 separation. The rift period corresponds to ages from the Early Neocomian to the Early

415 Aptian in the offshore portion of the basin. Deep asymmetric grabens were formed

416 where the Pendência Formation, one of the two main source rock of the Patiguar Basin,

417 deposited. The unit is later overlain by syntectonic sandstones followed by a general 
418 uplift that occurred at the end of the rift phase. The transitional stage corresponds to a

419 change from a rifting regime to a thermally subsiding basin (Bertani et al, , 1990).

420 During this period, the subsidence is slow and is characterized by the deposition of

421 sandstones, limestones and lagoonal rich shales of the Alagamar Formation, which

422 constitutes the second main source rock. Drift-phase sedimentation occurred during a

423 long period of thermal subsidence under marine conditions that lead to the formation of

424 stratigraphic and structural traps.

425

\section{$426 \quad 3.2$ The petroleum system}

427 The Potiguar Basin contains two main source rocks: the Pendência formation, a type I

428 lacustrine organic matter deposited during the rift phase, and the Alagamar formation, a 429 mixed organic rich carbonates and shales interbedded with deltaic sandstones, deposited

430 during the transitional period. The hydrocarbon formed from the Alagamar source rock

431 is mostly found in structural traps of the Açu sanstones formation.

432 The petroleum system in the Carnaubais trend is characterized by migration of

433 hydrocarbons generated in the offshore part of the basin towards the inland in low

434 depth reservoirs of the Açu formation sandstones. Long distance migration of the oil

435 from the offshore kitchen to the southern part of the basin was possible along the updip

436 trend through Aptian carrier beds.

437 There are a lot of evidences of biodegradation processes such as high NSO (resins and

438 asphaltenes) contents in the majority of the trapped hydrocarbons along the Carnaubais

439 trend in Açu formation reservoirs. Although there are slight differences between oil

440 fields that are close from each other, the Carnaubais trend clearly shows an increasing 
441 intensity of biodegradation (Behar et al., 2006, de Barros Penteado et al., 2007) in a

442 direction from the deeper and most offshore reservoirs in the northeast, to the most

443 shallowest and onshore reservoirs in the southwest. As the hydrocarbons migrated over

444 a long distance, the differences in the biodegradation magnitudes were mostly explained

445 by the residence time (de Barros Penteado et al., 2007; Haeseler et al., 2010) and the

446 differences of hydrocarbons generated during the maturation of the organic matter

447 (England et al., 1991).

448 As explained in the previous section, the hydrocarbon fluid composition is controlled by

449 PVT, thermal and biogenic factors. Thus the selected compositional approach is derived

450 from a previous work of Behar et al. (2008) about the kerogen thermal cracking and

451 from previous works of de Barros Penteado et al. (2007), Behar et al., (2006) and

452 Haeseler et al. (2010) on biodegradation rates and on microbial preferences.

453 Consequently, a 12 classes description of the kerogen cracking was selected to account

454 for both thermal and microbial effects (Table 1). The main changes brought to the

455 kerogen cracking model proposed by de Barros Penteado et al. (2007) to account for the

456 biogenic aspects concern the splitting of the saturated $\mathrm{C}_{14+}$ fraction into 3 classes (n-

457 alkanes, iso-alkanes and cyclo-alkanes) due to critical differences in their

458 biodegradability. Their respective fractions was derived from the composition of the oil

459 composition of the non-biodegraded oil from the ARG2 field (Haeseler et al., 2010).

\subsection{D Numerical model}

462 Numerous studies have already been dedicated to the investigation of the

463 biodegradation processes in the Potiguar basin (Behar et al., 2006; de Barros Penteado 
464 et al., 2007; Haeseler et al., 2010) and aimed at modelling the petroleum system history 465 (de Barros Penteado et al., 2007). The 2D numerical model of the Potiguar basin that is 466 used in the present study is derived from the model previously proposed by de Barros

467 Penteado et al. (2007) and has been updated to improve the thermal history of the basin.

468 Although this model is in 2D, it has been considered as significant enough to account

469 for the migration at the basin scale since hydrocarbon migration in the basin is assumed

470 to follow the axis of the Carnaubais trend from the offshore kitchen in the northeast to

471 the Açu oil fields in the southwest (Fig. 5).

472 As explained in the section describing the mechanisms that control biodegradation

473 processes, temperature plays a key role in the biodegradation rate. This is why a special 474 care has been taken to adjust the temperature fields in the Potiguar basin. The results of 475 the thermal calibration obtained with the 2D model are illustrated in Fig. 6 and reported 476 in the following table (Table 2).

477 The thermally calibrated model show a very good match (less than $3.0^{\circ} \mathrm{C}$ misfit)

478 between measured and simulated present day temperatures. This calibration step is very 479 important to insure a realistic description of the biodegradation rates within the Potiguar 480 basin since temperature plays also an important role in the description of the organic 481 matter maturation. Kinetic schemes elaborated by Behar et al. (2007) from source rock 482 samples of the Potiguar basin are adapted for describing the PVT and the thermogenic 483 transformation of the organic matter. They were adjusted to be also consistent with a 484 compositional description useful for biodegradation processes. The stoechiometric 485 coefficients used in the Potiguar source rock kinetic scheme are described in table 1.

486 Table 3 illustrates the results of oil composition in the ARG2 field obtained using the 487 thermally calibrated 2D model previously described with a simulation including 
maturation and migration of the hydrocarbons. In this simulation, the biodegradation processes were not modeled so that simulated petroleum composition can be compared with petroleum composition in fields that are known to contain non-biodegraded oil such as in the ARG2 field. These results, obtained after some minor adjustments of the 492 parameters of the kinetic scheme proposed by Behar et al. (2007) for the NSO cracking, 493 show a very good match between observed and simulated composition. The model can 494 be considered as well calibrated for the thermal aspects as well as for the compositional aspects. The module describing the biodegradation processes can then be activated.

Calibration parameters of this biodegradation module are mainly the microbial activity

497 versus temperature and compositional microbial preferences (relative biodegradation 498 rates). The selected microbial activity curve as a function of the temperature (Fig. 2) is taken and adapted from Wellsbury at al. (1997). The biodegradation rate in the temperature range of $40^{\circ} \mathrm{C}$ and $50^{\circ} \mathrm{C}$ was slightly increased. Concerning relative

501 biodegradation compositional rates, a first try has been made using coefficients

502 resulting from the work of Haeseler et al. (2010). They were later adjusted in order to 503 better match the composition observed in the biodegraded fields. Differences between coefficients determined for the BioClass approach of Haeseler et al. (2010) and the values used in this work are due to the fact Bioclass is a static 0D concept not fully

506 coupled to the migration processes whereas a dynamic approach is followed in this 507 work. Indeed BioClass assumes that, for all reservoirs, the initial oil composition is the 508 same. Our model shows that hydrocarbons reaching the most southwestern reservoirs 509 have already been biodegraded during their migration. The relative biodegradation rates 510 used in the Potiguar simulation are presented in the following table (Table 4). All the 
511 other chemical compounds such as NSO (resins and asphaltenes) or non-hydrocarbon

512 gases are considered as non-biodegradable.

513 The other parameters corresponding to biodegradation aspects chosen for the Potiguar

514 model are listed here below:

515 - Pasteurization temperature: $90^{\circ} \mathrm{C}$

516 - Interval of saturations associated with biodegradation processes: [20\%; $80 \%]$

517 Reference porosity $\left(\varphi_{0}\right): 30 \%$

518 - Hydrocarbon degradation rate $\left(M_{0}\right): 155 \mathrm{~kg} / \mathrm{My} / \mathrm{m}^{3}$ of rock

519 The first important result is that the activation of the biodegradation module does not

520 prevent from filling the known fields with oil (Fig. 7). Then, the simulated compositions

521 in the biodegraded fields are illustrated in Fig. 8 and compared with measured

522 compositions. A very good match can be observed all along the Carnaubais trend with

523 very altered oil in the shallowest fields of the South western part of the basin and less

524 biodegraded fields towards the offshore part of the Potiguar basin. Variations of oil

525 composition in terms of API gravity in the Potiguar basin are represented in Fig. 9.

526 The field for which the results are not as good as for the other fields is the ARG2 field.

527 The obtained results predict a more biodegraded oil that was is actually measured.

528 However this field is known to have compartments with non-biodegraded oil. So the

529 difference between simulated and measured compositions of the ARG2 field could be

530 explained by mixing of biodegraded and fresh. This hypothesis is consistent with the

531 observation that fresher oil is coming in the last stages of the basin history from deeper

532 layers (Fig. 9 and 10). 
533 Using the formalism described in section 2.5, a biodegradation index was computed

534 during the simulation of the Potiguar basin. Results, presented in Fig. 10, emphasize the

535 fact that the hydrocarbon mass loss is at least of $25 \%$ in the considered fields and can be

536 as high as $65 \%$ in the most biodegraded oils of the basin. These results which give a

537 complete picture of the state of biodegradation along the Carnaubais trend are consistent

538 with those of Behar et al. (2006).

539

5404 Results and Discussions

541 A new approach consistent with general observations on key controlling factors of the

542 biodegradation processes such as the relationship of microbial activity versus

543 temperature and the concept of paleo-pasteurization has been developed. It provides a

544 quantitative and predictive solution for modeling biodegradation processes in a fully

545 coupled way with migration and accumulation processes. This is a major step in the

546 correct description of petroleum systems where biodegradation plays a key role on the

547 quality and quantity of hydrocarbon in place in the reservoirs. Till now only post-

548 processing methods were available and the application on natural cases should

549 demonstrate the great importance of accounting for all migration mechanisms in a fully

550 coupled way to correctly assess prospects potential.

551 This new approach goes a step forward than the Biodexx method (Blumenstein et al.,

552 2008), since the oil-water contact is precisely localized. Thus temperature, microbial

553 activity and degradation rate can be accurately computed and are directly consistent

554 with the whole petroleum system history. No assumption has been made on the 
mechanisms that drive the reservoir filling. The complete description of hydrocarbon

556 saturation in the migration paths as well as in the reservoirs relies on the Darcy's law.

557 The application of the new approach on the Potiguar basin leads to very good results

558 consistent with measured compositions and oil qualities. The Potiguar basin shows no

559 evidence of paleo-pasteurization. The comparison of the evolution of temperatures of

560 fields covering a wide range of biodegradation degrees demonstrates that even if

561 biodegradation processes are very dependent on temperature, this latter cannot explain

562 by itself the variation of biodegradation in the Potiguar basin. The migration history

563 shows that hydrocarbons undergo successive steps of biodegradation while migrating

564 along the migration path emphasizing the importance to tightly link biodegradation and

565 migration processes. The basin model was able to simulate very fine lateral and vertical

566 variations of oil quality even in the reservoirs. It has been possible to explain the

567 difference of oil quality as well as the presence of non-biodegraded oil in the ARG2

568 field by the arrival of fresh oil from a deeper carrier bed latter in the basin history.

569 Some of the results obtained are less intuitive and should lead to further investigations.

570 For instance the results obtained on the Potiguar basin model show that gaseous

571 fractions increase with increasing biodegradation due to the loss of a great part of liquid

572 fractions. Thus, even if the API gravity increases with biodegradation, contrary to what

573 could have been expected the viscosity of the hydrocarbon phase does not increase. This

574 explains the fact that even if the oil is biodegraded it can still migrate which is

575 consistent with observations on the Potiguar basin. This effects could be even more

576 important than expected as the products of the biodegradation processes (carbon

577 dioxide, methane...) are not taken into account in this approach. Further work should

578 investigate the effect of these gases produced during biodegradation of hydrocarbon 
579 fluids on oil properties (quality, viscosity, density...) taking into account dissolution

580 into water and changes in fluid phase. Results of work still in progress, which focuses

581 on biodegradation rates and microbial consumption preferences through laboratory

582 experiments, could also be integrated in the approach.

\section{Acknowledgements}

\section{References}

587 Adams, J., Riediger, C., Fowler, M.G. \& Larter, S.R. (2006) Thermal controls on biodegradation around the Peace River tar sands: Palaeopasteurization to the west. J. Geochem Explor., 89 (1-3), 1-4.

Behar, F., Lorant \& F. Mazeas, L. (2008) Elaboration of a new compositional kinetic schema for oil cracking. Organic Geochemistry, 39, 764-782.

Behar, F., Budzinski, H., de Barros Penteado, H.L. \& Lorant, F. (2006) Study of the biodegradation processes along the Carnaubais trend, Potiguar Basin (Brazil) Part I. Organic Geochemistry, 37-9, 1042-1051

Bernard, F.P. \& Connan, J. (1992) Indigenous microorganisms in connate waters of many oilfields: a new tool in exploration and production techniques. SPE 24811. In: $67^{\text {th }}$ Annual Technical Conference and exhibition of the Society of Petroleum Engineers, Washington D.C., October 1992, 467-476.

Bertani, R.T., Costa, I.G. \& Matos, R.M.D. (1990) Evolução tectono-sedimentar, estilo estructural e "habitat" do petróleo na Bacia Potiguar. In: Gabaglia, J.P.R., Milani, 
Blanchet, D., Kowalewski, I., Magnier, C., Marchal, R., Grabowski, A. \& Huc, A.Y. (2005) In: Vandecasteele, J.P. (Ed.), Microbiologie pétrolière, concepts, implications environnementales, applications industrielles, vol. 2. Editions Technip, Paris, 629-675.

Blumenstein, I.O., Kross, B.M., di Primio, R., Rottle, W., Muller, E., Westerlage, C. \& Littke, R. (2008) Biodegradation in numerical basin modeling a case study from the Gifhorn Trough, N-Germany. Int. J. Earth Sci (Geol Rundsch), 97, 1115-1129.

Carpentier, B., Behar, F., de Barros Penteado, H.L. \& Lorant, F. (2005) New approach

614 Connan, J. (1984) Biodegradation of crude oils in reservoirs. In: Brooks, J. Welte D.H.

615 (eds) Advances in petroleum geochemistry. Academic, London, 299-335.

616 Cragg, B.A., Law, K.M., O'Sullivan, G.M. \& Parkes, R.J. (1999) Bacterial profiles in deep sediments of the Alborean sea, Western Mediterranean, sites 976-978. In

624 de Barros Penteado, H.L., Behar, F., Budzinski, H. \& Lorant, F. (2007) Study of the Zahn, R., Comas, M.C., Klaus, A., (Eds), Proceedings ODP Scientific Results, 161; College Station, Texes (Ocean Drilling Program), 433-438.

Cragg, B.A., Law, K.M., Cramp, A. \& Parkes, R.J. (1997) Bacterial profiles in Amazon fan sediments, Sites 934, 940. In Flood, R.D., Piper, D.J.W., Klaus, A., Peterson, biodegradation processes along the Carnaubais trend, Potiguar Basin (Brazil) Part I. Organic Geochemistry, 38-8, 1197-1211. 
627 Dolfing, J., Larter, S.R. \& Head, I.M. (2008) Thermodynamic constraints on methanogenic crude oil biodegradation. ISME Journal, 2, 442-452.

Dzou, L. \& He, D. (2009) The advantages of Interactive Fluid Property modeling. AAPG Hedberg Conference on: "Basin and Petroleum System Modeling: New Horizons in Research and applications". May $3^{\text {rd }}-7^{\text {th }}, 2009$, Napa, California, USA.

633 England, W.A., Mann, A.L. \& Mann, D.M. (1991) Migration from source to trap. AAPG Special Bulletin, 3, 23-47.

Haeseler, F., Behar, F., Garnier, D. \& Chenet, P.Y. (2010) First stoichiometric model of oil biodegradation in natural petroleum systems. Part I - The BioClass 0D approach. Organic Geochemistry, 41, 1156-1170.

Head, I.M., Jones, D.M., \& Larter, S.R. (2003) Biological activity in the deep subsurface and the origin of heavy oil. Nature, 426 (6964), 344-352.

Johns, R.B. (1986) Biological Markers in the Sedimentary Records. Elsevier, Amsterdam, 364 pp.

Jones, D.M., Head, I.M., Gray, N.D., Adams, J.J., Rowan, A.K., Aitken, C.M., Bennett, B., Huang, H. Brown, A., Bowler, B.F., Oldenburg, T., Erdmann, E. \& Larter, S.R. (2008) Crude oil biodegradation via methanogenesis in subsurface petroleum

646 Kowalewski, I., Carpentier, B., Huc, A.Y., Magnier, C. \& Delamaide, E. (2001) Geochemical study of biodegraded heavy oils of Wabasca sand deposits (Canada). In: $20^{\text {th }}$ International Meeting on Organic Geochemistry, September $10^{\text {th }}-14^{\text {th }}$, Nancy, p. 87. 
Larter, S.R., Huang, H., Adams, J., Bennet, B., Jokanola, O., Oldenburg, T., Jones, M., Head, I.M., Riediger, C. \& Fowler, M. (2006) The Controls on the composition of biodegraded oils in the deep subsurface. Part 2 - geological controls on subsurface biodegradation fluxes and constraints on reservoir-fuilds property prediction. AAPG Bulletin, 90, 921-938.

Larter, S.R., Wilhelms, A., Head, I.M., Koopmans, M.P., Aplin, A. di Primio, R., Zwach, C., Erdmann, M. \& Telnaes, N. (2003) The controls of the composition of biodegraded oils in the deep surface - Part 1: biodegradation rates in petroleum reservoirs. Organic Geochemistry, 34, 601-613.

Magnier, C., Kowalewski, I., Carpentier, C. Huc, A.Y., Delamaide, E. \& de Barros Penteado, H.L. (2001) Tentative quantification of the extent of biodegradation in oil fields using heavy metal content. In: $20^{\text {th }}$ International Meeting on Organic Geochemistry, September $10^{\text {th }}-14^{\text {th }}$, Nancy, $413-414$.

Moldowan, J.M., Albrecht, P. \& Philp, R.P. (1992) Biological Markers in Sediments and Petroleum. Prentice Hall, New Jersey, 411 pp.

Parkes, R.J., Cragg, B.A. \& Wellsbury, P. (2000) Recent studies on bacterial populations and processes in subseafloor sediments: a review. Hydrogeol. Journal, $8,11-28$

Peters, K.E., Walters, C.C. \& Moldowan, J.M. (2005) The Biomarker Guide, $2^{\text {nd }}$ ed. Biomarkers and Isotopes in Petroleum Exploration and Earth History, vol. 2.

671 Roadifer, R.E. (1987) Size distribution of the world's largest oil and tar accumulations. In: Meyer, R.F. (Ed.), Exploration for Heavy Crude Oil and National Bitumen. 
AAPG Studies in Geology, Vol. 25, American Association of Petroleum Geologists, Tulsa, 3-23.

675 Trindade, L.A.F., Brassell, S.C. \& Santos Neto, E.V. (1992) Petroleum migration and mixing in the Potiguar Basin, Brazil. AAPG Bulletin, 76, 1903-1924.

Walters, C.C., Freund, H., Kelemen, S.R., Braun, A.L. \& Wenger, L.M. (2009) Predicting Oil Quality - Simulating Reservoir Alteration Processes. AAPG Hedberg Conference on: "Basin and Petroleum System Modeling: New Horizons in Research and applications". May $3^{\text {rd }}-7^{\text {th }}, 2009$, Napa, California, USA.

Wellsbury, P., Goodman, K., Barth, T., Cragg, B.A., Barnes, S.P. \& Parkes, R.J. (1997) Deep marine biosphere fuelled by increasing organic matter availability during burial and heating. Nature, 388, 573-576.

684 Wenger, L.M., Davis, C.L. \& Isaksen, G.H. (2001) Multiple Controls on Petroleum Biodegradation and Impact on Oil quality. SPE 71450, Society of Petroleum Engineers.

Wilhelms, A., Erdmann, M. \& Larter, S.R. (2004) Easy-Fest versus BDI uncertainties in Predrill prediction of biodegradation degree in subsurface petroleum reservoirs. AAPG Bulletin, 88, (13) (Supplement).

690

691

692

693

Wilhelms, A., Larter, S.R., Head, I.M., Farrimond, P., di Primio, R. \& Zwach, C. (2001) Biodegradation of oil in uplifted basins prevented by deep-burial sterilization. Nature, 411, 1034-1037.

Yu, A.Z., Cole, G., Grubitz, G. \& Peel, F. (2002) How to predict biodegradation risk and reservoir fluid quality. World Oil, April $1^{\text {st }}-5^{\text {th }} 2002$. 
695 Zengler, K., Richnow, H.H., Rossello-Mora, R., Michaelis, W. \& Widdel, F. (1999)

696 Methane formation from long-chain alkanes by anaerobic microorganisms.

697 Nature, 401, 266-269.

698 
700 Table 1 Stoechiometric coefficients for kerogen cracking $(\mathrm{mg} / \mathrm{g})$.

\begin{tabular}{lcc}
\hline Compound class & PT beds & Upanema Mb. \\
\hline $\mathrm{CO}_{2}$ & 92 & 90 \\
$\mathrm{C}_{1}-\mathrm{C}_{5}$ & 36 & 20 \\
$\mathrm{C}_{6}-\mathrm{C}_{14}$ sat & 22 & 22 \\
$\mathrm{C}_{6}-\mathrm{C}_{14}$ aro & 6 & 6 \\
$\mathrm{C}_{14+}$ n-alkanes & 11 & 12 \\
$\mathrm{C}_{14+}$ iso-alkanes & 16 & 17 \\
$\mathrm{C}_{14+}$ cyclo-alkanes & 24 & 26 \\
$\mathrm{C}_{14+}$ aro & 12 & 15 \\
$\mathrm{C}_{14+}$ NSO & 15 & 9 \\
$\mathrm{C}_{14+}$ NSO-retained & 138 & 83 \\
Kero2 & 628 & 700 \\
Dead kerogen & 0 & 0 \\
\hline
\end{tabular}

701

702 Table 2 Comparison of measured and simulated present-day temperatures in the

703 Potiguar basin.

704

\begin{tabular}{lcc}
\hline Field & $\begin{array}{c}\text { Measured } \\
\text { temperature } \\
\left({ }^{\circ} \mathbf{C}\right)\end{array}$ & $\begin{array}{c}\text { Simulated } \\
\text { temperature } \\
\left({ }^{\circ} \mathbf{C}\right)\end{array}$ \\
\hline GMR & 47.5 & 47.2 \\
FP & 42.9 & 45.7 \\
MAG1 & 39.8 & 40.8 \\
ARG2 & 38.1 & 36.4 \\
ET & 38.6 & 37.2 \\
\hline
\end{tabular}


706 Table 3 Comparison of simulated and measured oil composition of a non-biodegraded

707 oil from the ARG2 field.

\begin{tabular}{lcc}
\hline Compound class & $\begin{array}{l}\text { Measured composition in non- } \\
\text { biodegraded oil of the ARG2 } \\
\text { field (\%) }\end{array}$ & $\begin{array}{l}\text { Simulated composition in } \\
\text { non-biodegraded oil of the } \\
\text { ARG2 field (\%) }\end{array}$ \\
\hline $\mathrm{C}_{6}-\mathrm{C}_{14}$ & 32 & 32 \\
$\mathrm{C}_{14+}$ n+iso alkanes & 23 & 22 \\
$\mathrm{C}_{14+}$ cyclo-alkanes & 21 & 20 \\
$\mathrm{C}_{14+}$ aro & 9 & 10 \\
$\mathrm{C}_{14+} \mathrm{NSO}$ & 15 & 14 \\
\hline
\end{tabular}

708

709 Table 4 Relative biodegradation rate of the biodegradation compound classes used to

710 describe the hydrocarbon phase.

\begin{tabular}{lc}
\hline Compound & $\begin{array}{c}\text { Relative } \\
\text { biodegradation rate }\end{array}$ \\
\hline $\mathrm{C}_{6}-\mathrm{C}_{13}$ sat & 0.630 \\
$\mathrm{C}_{6}-\mathrm{C}_{13}$ aro & 0.140 \\
$\mathrm{C}_{14+}$ n-alkanes & 0.121 \\
$\mathrm{C}_{14+}$ iso-alkanes & 0.078 \\
$\mathrm{C}_{14+}$ cyclo-alkanes & 0.031 \\
$\mathrm{C}_{14+}$ Aro & 0.000 \\
\hline
\end{tabular}

711 


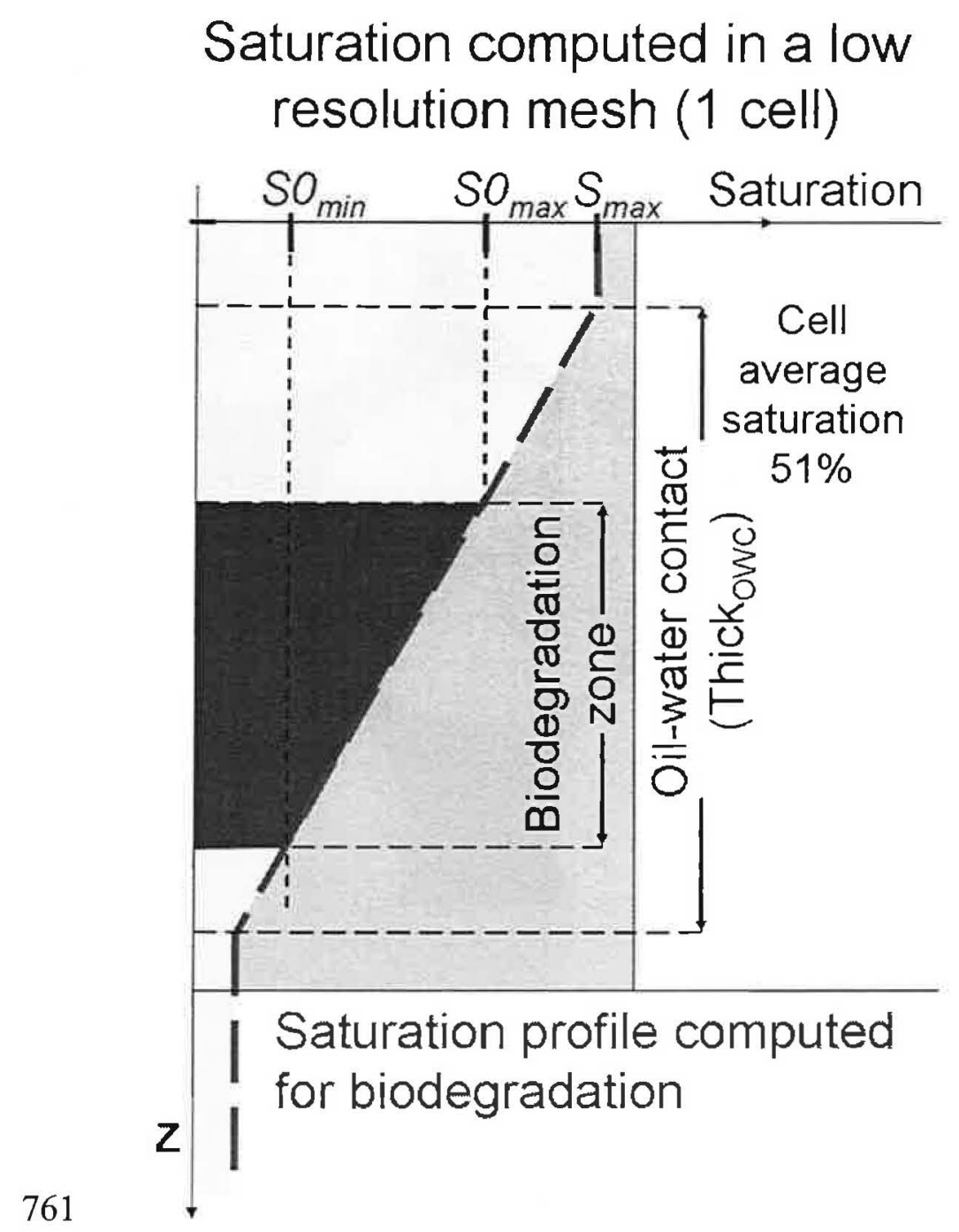

Saturation computed in a high resolution mesh (7 cells)

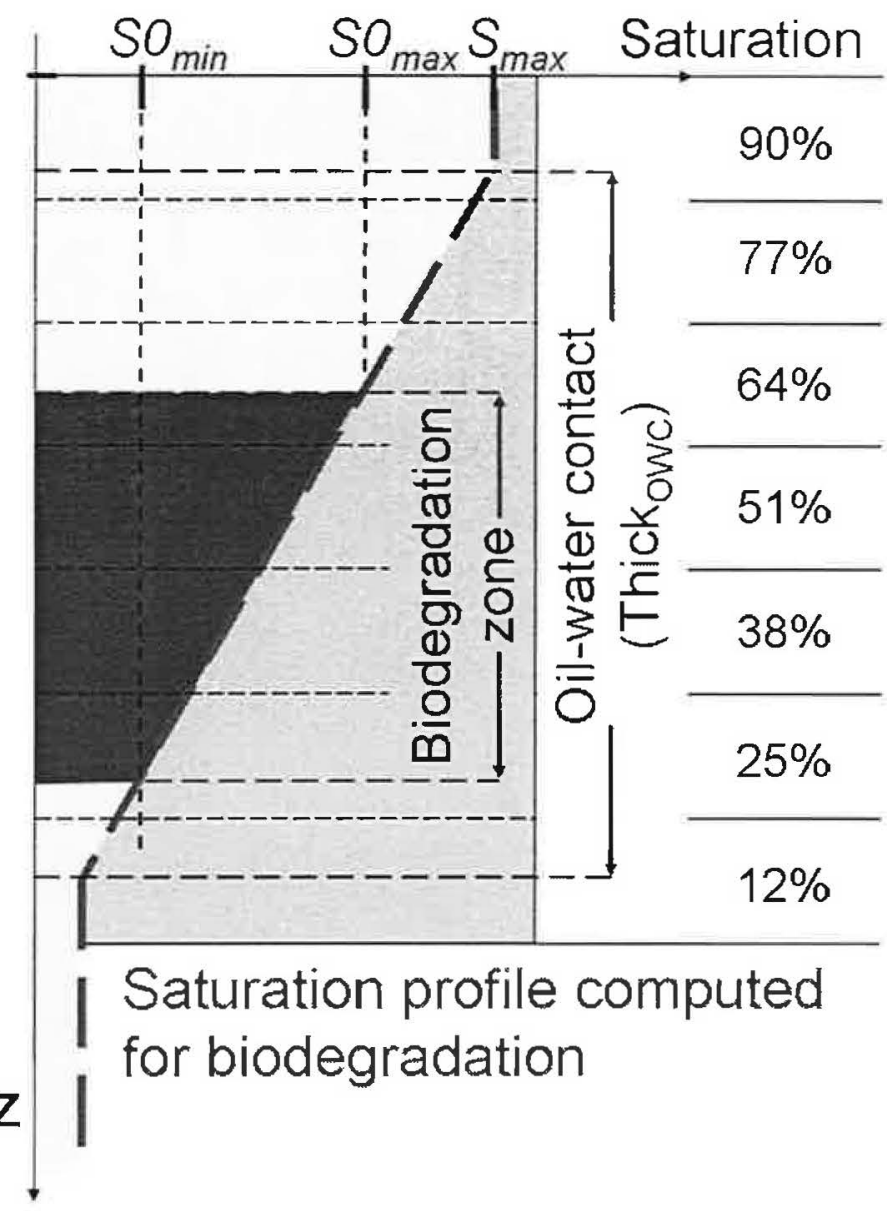



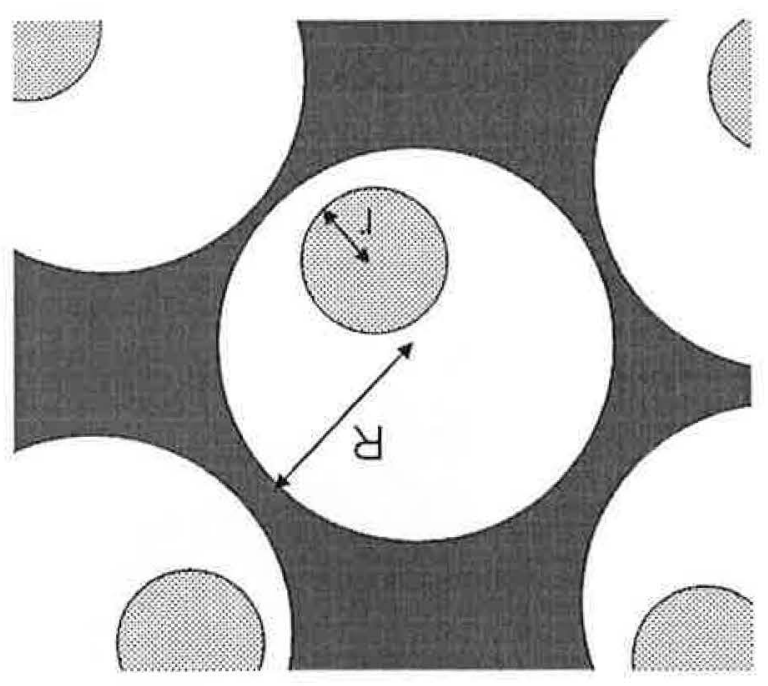
Figure 3

766

767

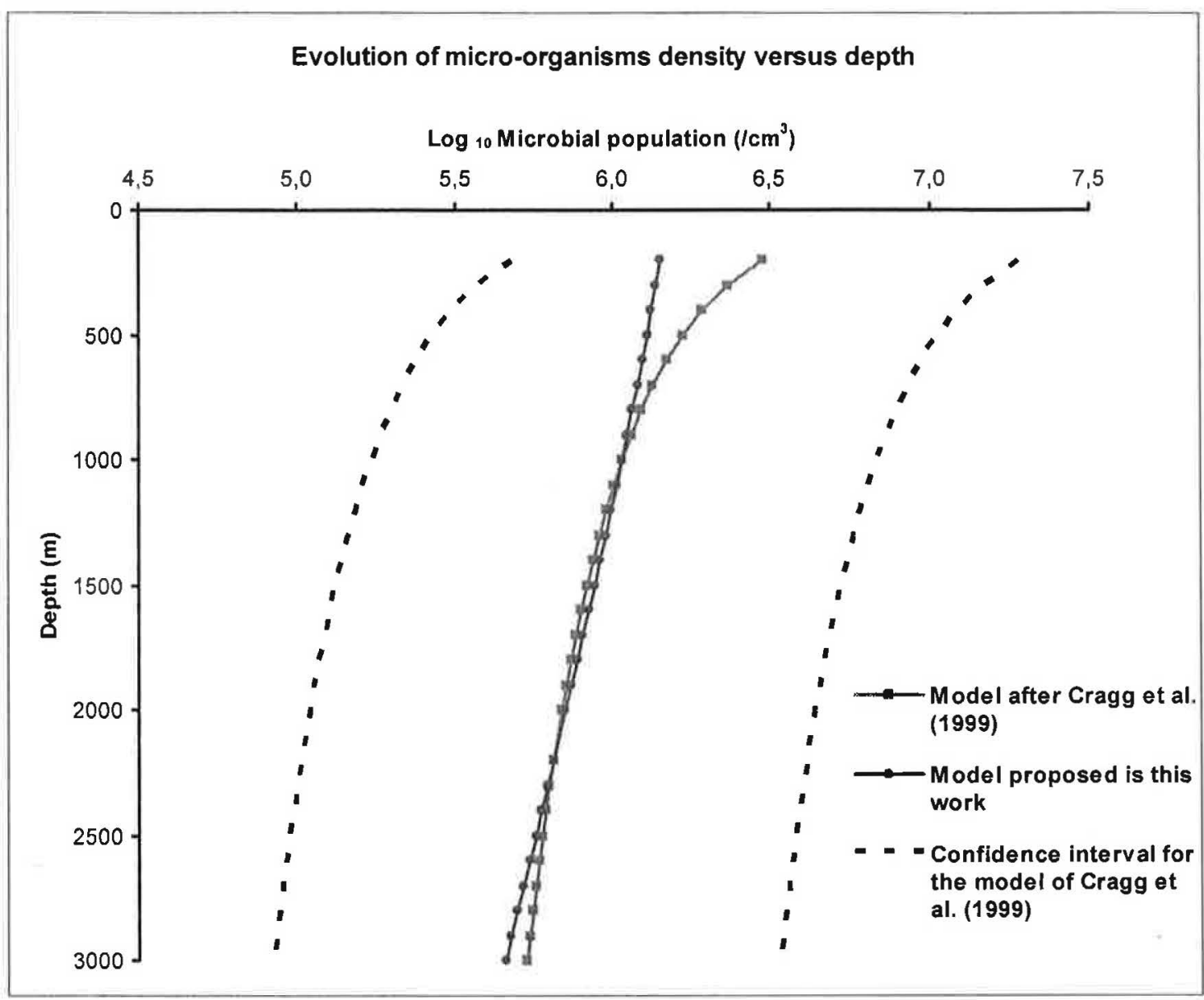


$\left(0_{0}\right) \perp$

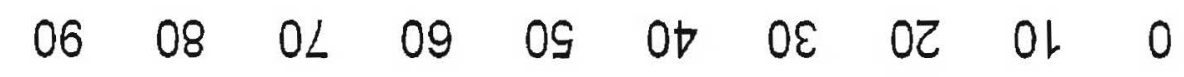

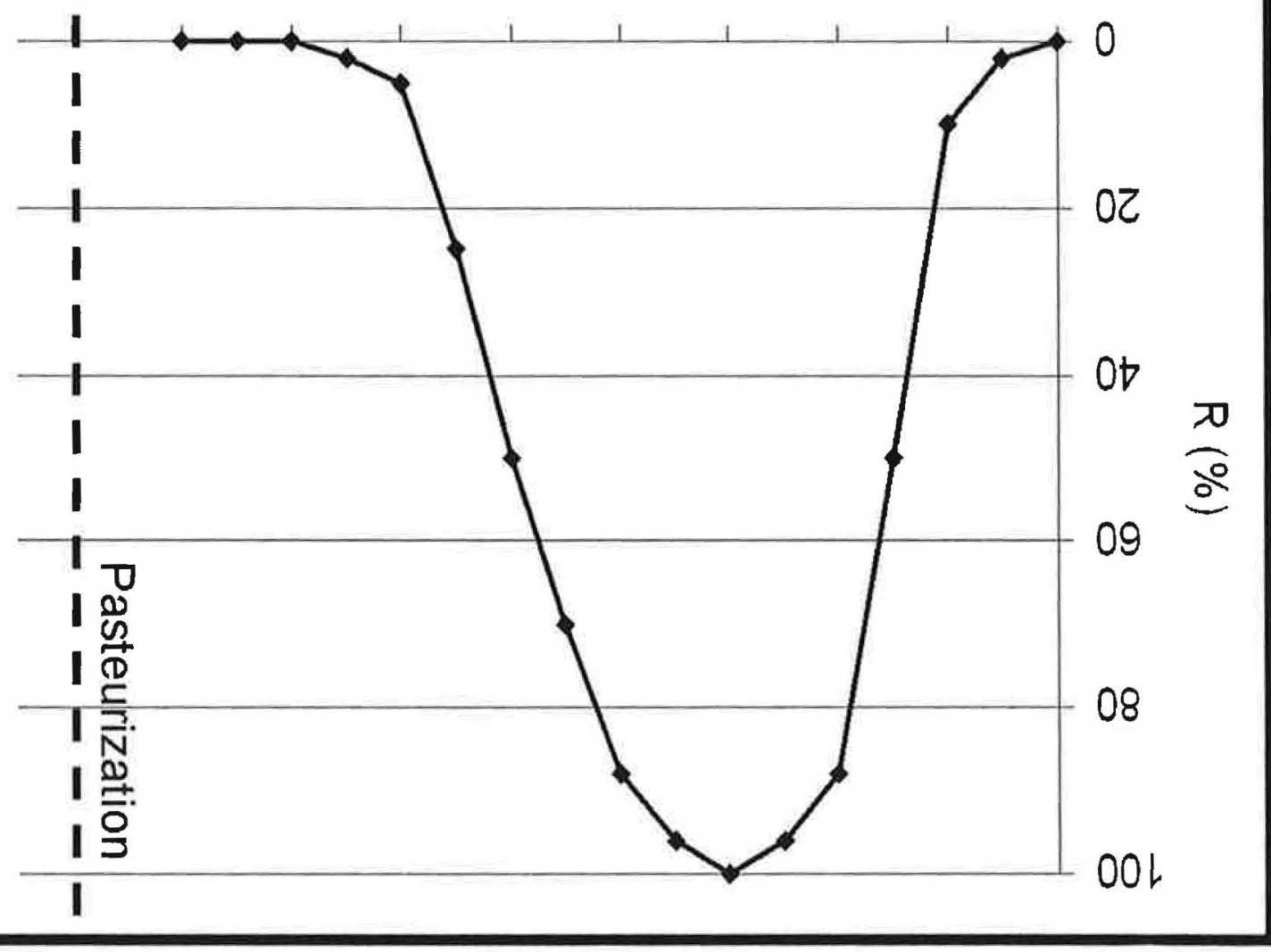

† อ.กถิเม $89 L$ 
$771 \quad$ Figure 5

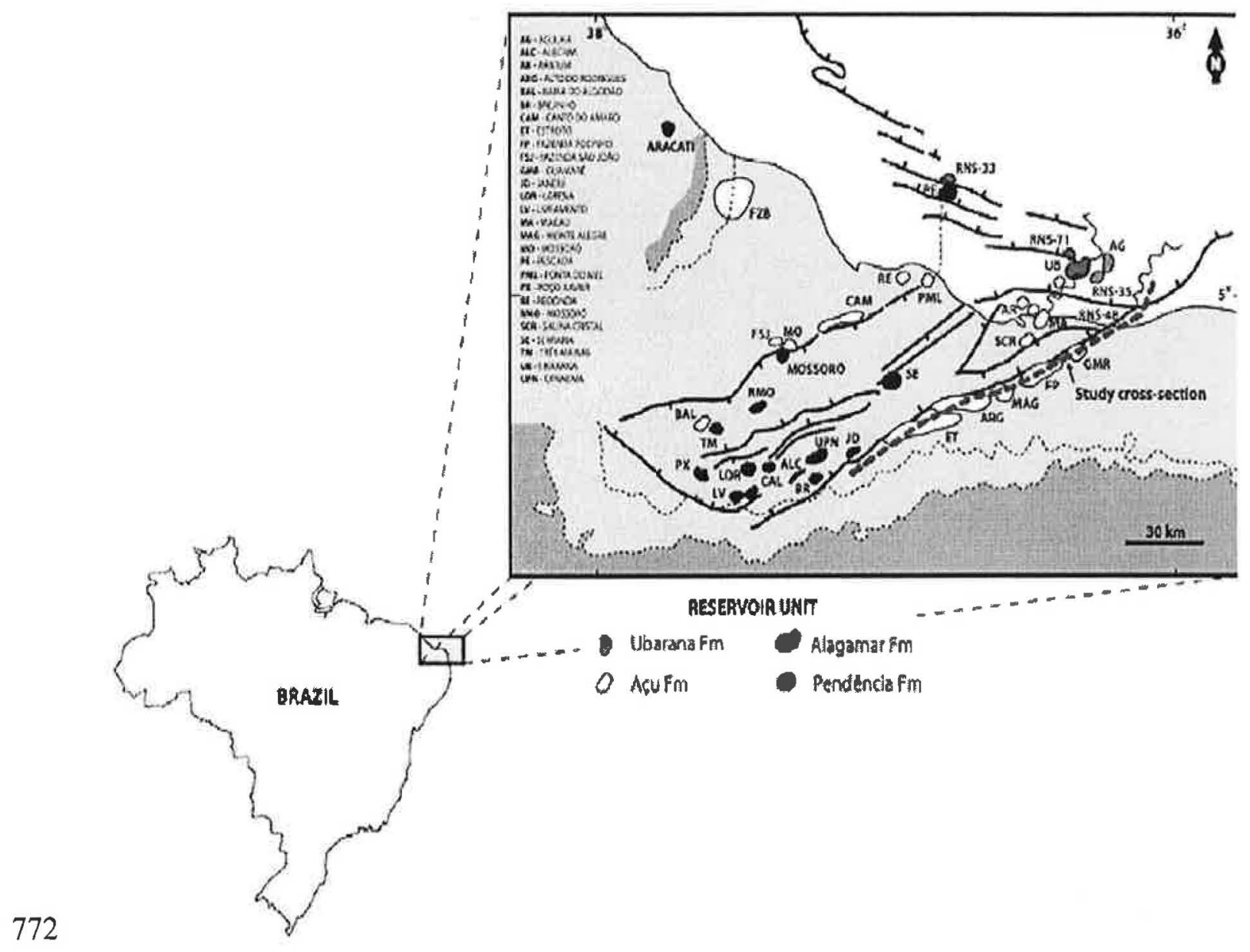


$774 \quad$ Figure 6

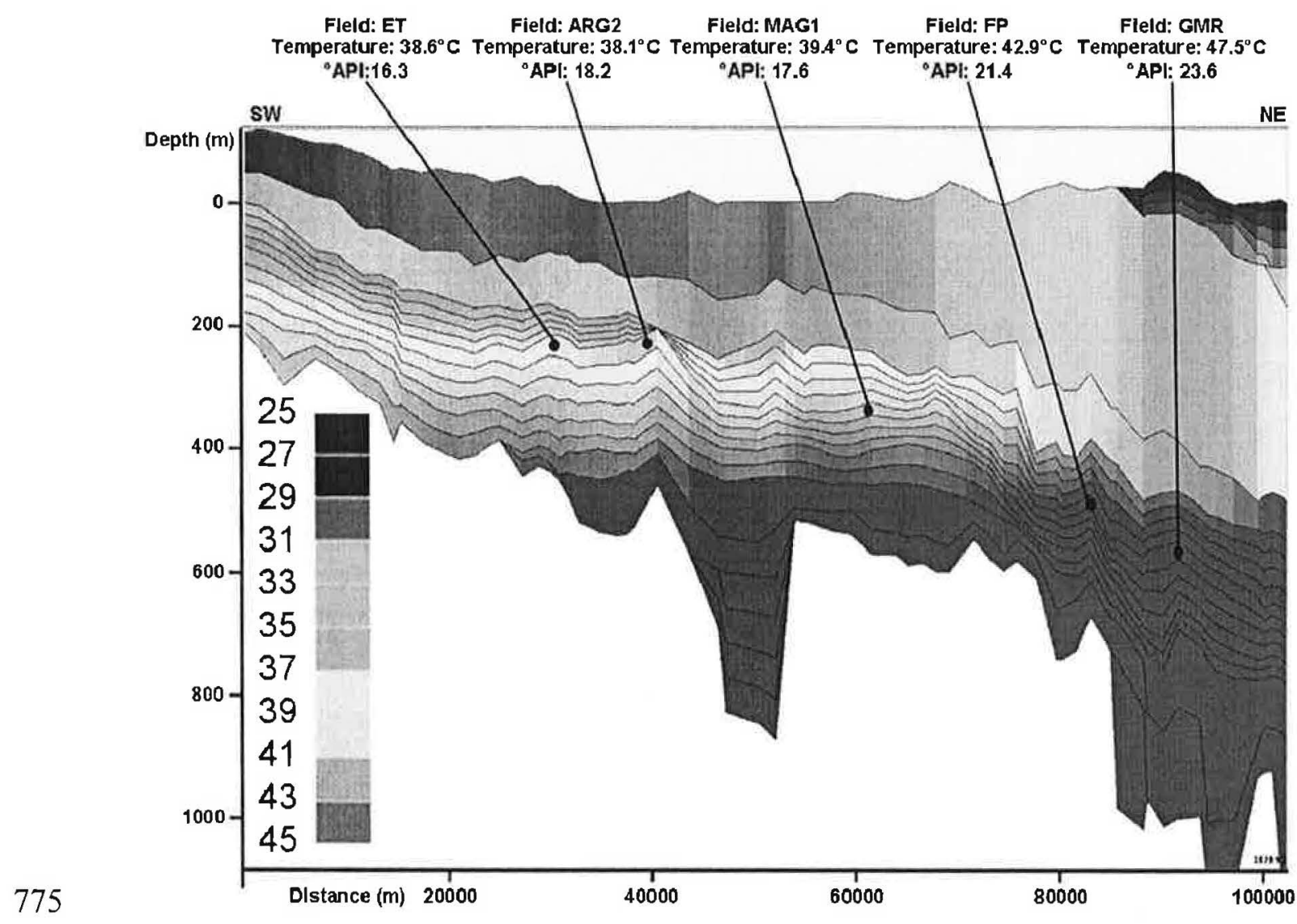




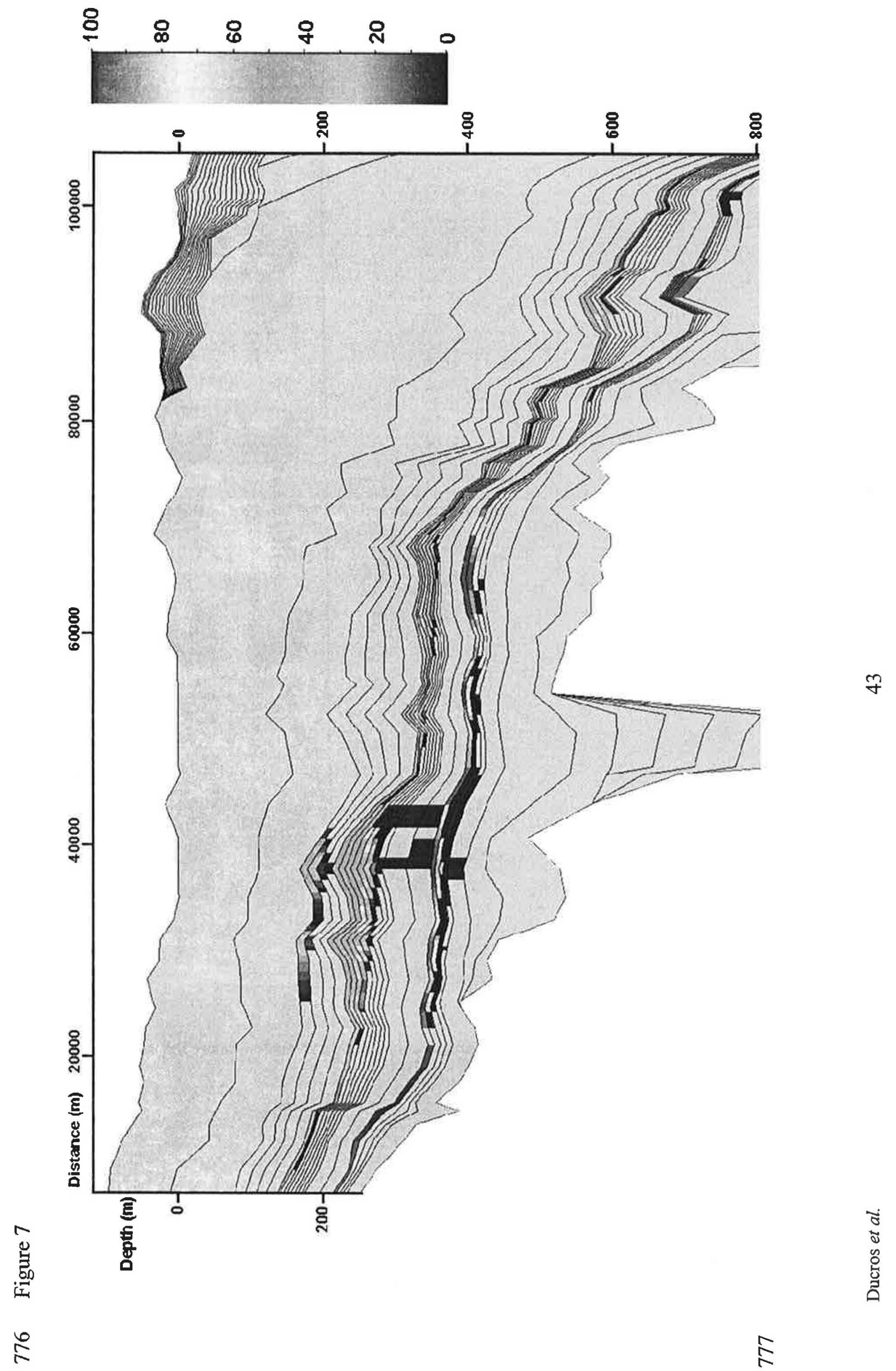


$779 \quad$ Figure 8

Fimulated




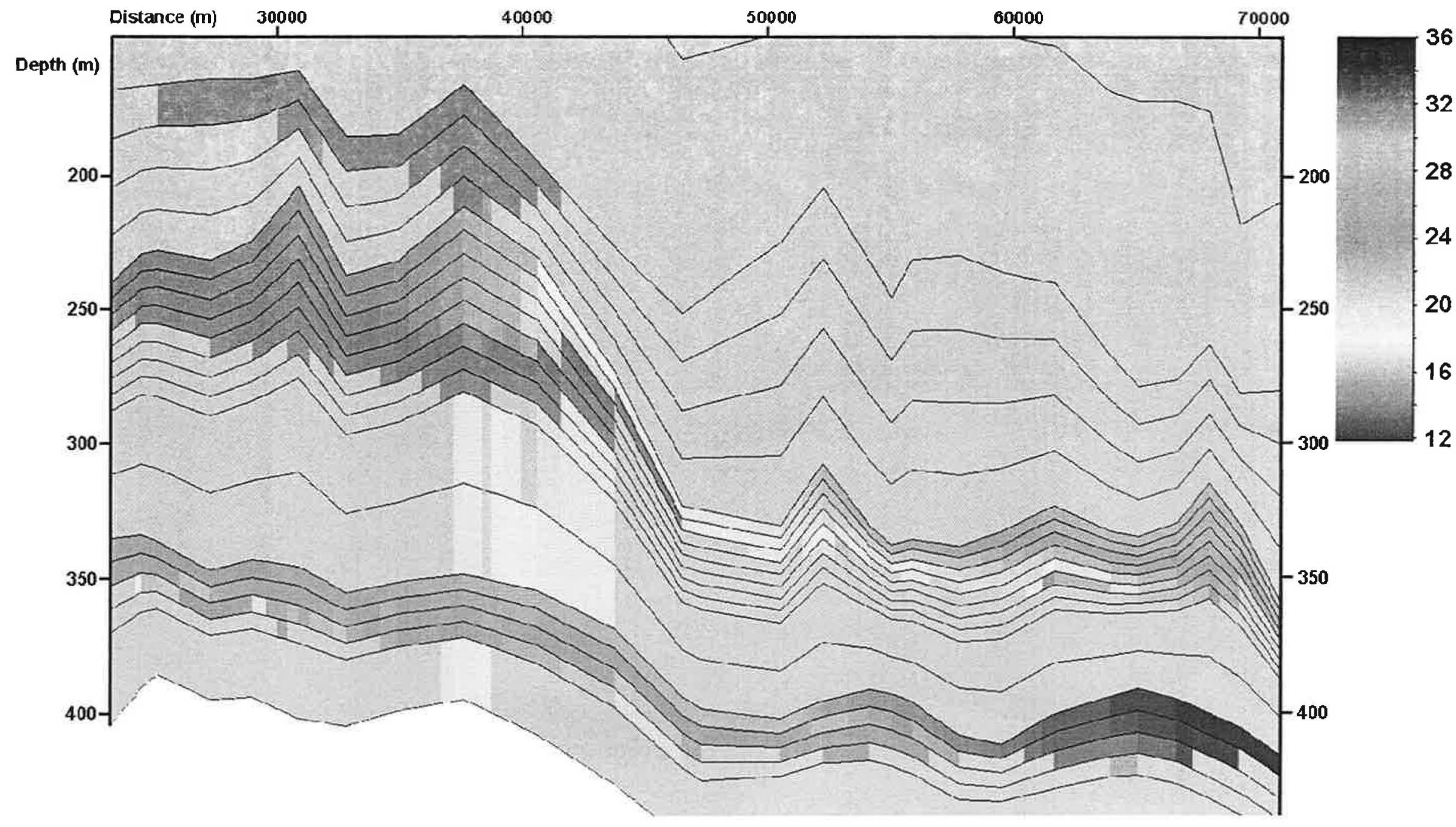




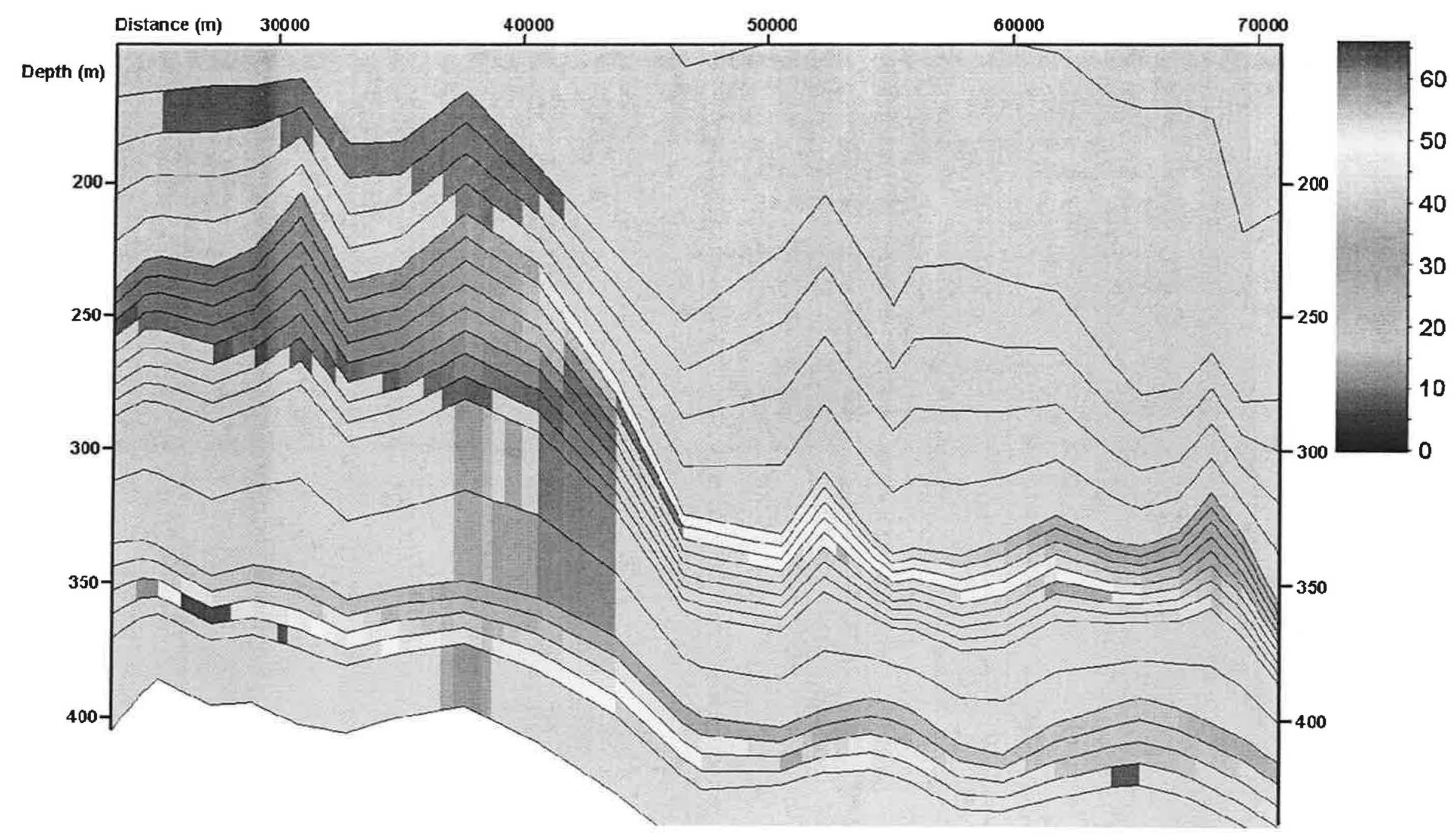

